\title{
GROWTH AND YIELD OF MAIZE (ZEA MAYS L.) INOCULATED BY MYCORRHIZAE AND INTERCROPPING WITH MUNGBEAN IN DRY LAND
}

\author{
Susanti Yuliana*, Hidayah Baiq Nurul, Herawati Nani, Aisah Ai Rosah \\ Institute for Assessment of Agricultural Technology (Balai Pengkajian Teknologi Pertanian), \\ West Nusa Tenggara Province, Indonesia \\ *E-mail: yuliana99.ys@gmail.com
}

\begin{abstract}
Maize productivity in Indonesia currently is still around $5.1 \mathrm{t} / \mathrm{ha}$. This result is still low when compared to research results which have reached 8.0 t/ha on dry land. One of the reasons for the low productivity of maize is the lack of application of cultivation technology at the farmers level. There is still possibility to increase the productivity of composite maize varieties in dry land by increasing the plant population. In addition, application of an intercropping system of maize with legumes can help increase maize yields. This study was conducted in Labuhan Lombok Village, Pringgabaya District, East Lombok Regency, West Nusa Tenggara Province of Indonesia from August to December 2019. The experiment was arranged according to a Randomized Block Design by testing 2 treatment factors, namely (1) mycorrhizal inoculation consisting of two levels ( $\mathrm{MO}=$ without mycorrhizal inoculation; $\mathrm{M} 1$ = with mycorrhizal inoculation), (2) the number of mungbean inserts consisting of three levels (D0 = maize cultivation without mungbean inserted; D1 = maize cultivation with 1 row of mungbean inserted; D2 = maize cultivation with 2 rows of mungbean inserted) and each treatment was replicated 3 times therefore 18 experimental plots were obtained. Results showed that maize cultivation in dry land and dry climate with double row planting system inoculated with mycorrhizae and insertion of two rows of mungbean was much better than inserting 1 row of mungbean because the difference in yield obtained was much smaller, namely $6 \%$ or $490 \mathrm{~kg}$ compared to monoculture yields, but from the results of the profit evaluation based on the calculation of the Land Equity Ratio, the insertion of 1 row of mungbean was much higher, namely 2.62 compared to the insertion of two rows of mungbean which only obtained a result of 2.25 .
\end{abstract}

\section{KEY WORDS}

Dry land, intercropping, maize, mungbean, mycorrhizae, productivity.

Maize (Zea mays L.) is a versatile plant, where almost all parts of the above-ground maize plant can be used for food, animal feed and industrial raw materials. In Indonesia, corn is the second staple food after rice, which is mostly consumed by the society in the form of processed products or semi-finished ingredients such as mixtures for making instant porridge, cakes, cake mixes and low-calorie beverage products.

The trend of corn consumption per capita of the population in Indonesia in the period 2014 to 2017 has increased by an average of $1.65 \%$ per year. In 2015 household corn consumption increased significantly $(22.63 \%)$ compared to 2014 from $1.459 \mathrm{~kg} / \mathrm{capita} / \mathrm{year}$ to $1.789 \mathrm{~kg} /$ capita/year, while in 2017 corn consumption decreased $(-17.13 \%)$ to 1.500 $\mathrm{kg} /$ capita/year and in the following year 2018 it increased by $9.33 \%$ or $1.640 \mathrm{~kg} /$ capita/year. On the other hand, the use of corn for animal feed far exceeds the use of corn for households, which ranges from 1.46 to 1.81 million tons with a growth rate of $2.31 \%$ per year. This is different from the total use of corn for industry, which in the period $2014-2018$ increased higher $6.37 \% / y e a r$ or 1.64 million tons. The increasing need of corn for animal feed is due to the growing development of broiler farming businesses (Muliany, 2018).

The increase in the need for corn consumption in Indonesia is also supported by an increase in national corn production. According to Bureau of Statistical data (2019) in 20142018 the average percentage increase in corn production reached $10.25 \%$. The increasing in production was due to an increase in harvested area, but national maize productivity was still 
around $5.1 \mathrm{t} / \mathrm{ha}$. This result is still low when compared to research results which have reached 8.0 t/ha on dry land (Jaya et al., 2017).

West Nusa Tenggara (WNT) is one of the provinces in Indonesia. Maize is the main crop that is widely cultivated in WNT Province. In the rainy season it is planted in dry land and in the dry season it is planted in rice fields. WNT Province maize production in $2013-$ 2015 tends to continue to increase, where the average increase was $18 \%$ but the increase in production is obtained due to an increase in the harvested area. Maize productivity in WNT Province is not much different from national maize productivity, which is $5.9 \mathrm{t} / \mathrm{ha}$. One of the reasons for the low productivity of maize is the lack of application of cultivation technology at the farmers level.

There is still possibility to increase the productivity of composite maize varieties in dry land by increasing the plant population. In addition, the application of an intercropping system of maize with legumes can help increase maize yields as reported by Wangiyana et al., (2018) that by increasing the number of rows of peanut planted with inserts between rows of maize can increase the weight of the cob per ha compared to without inserting peanut. Farida et al., (2018) also reported that intercropping of maize with mungbean was able to increase dry seed weight per clump and dry seed weight of maize per hectare compared to monoculture planting.

The involvement of Arbuscular Mycorrhizal Fungi (AMF) colonization in intercropping system can help improve the $\mathrm{N}$ transfer process due to the hyphal bridge that colonizes the roots of the two types of intercropping plants (Smith and Read, 2008). Another study also reported that the aerobic intercropping system of rice and soybean inoculated with AMF showed better growth and higher yields than plants that were not inoculated with AMF (Wangiyana, 2018).

The application of technology can be an alternative that can be done to help increase productivity and maize production in WNT province, as reported by Erawati et al., (2013) at the Field Laboratory (FL) location, maize production reached $10.4 \mathrm{t} / \mathrm{ha}, 10.1 \mathrm{t} / \mathrm{ha}, 9.9 \mathrm{t} / \mathrm{h}$ and $9.5 \mathrm{t} / \mathrm{ha}$ for the varieties of Bima 2, Bima 5, Bima 4 and Bisi 16 respectively, while in the Field School (FS) area, maize production of Bisi 16 variety was 6.5 t/ha and production outside Field School only reached $3.6 \mathrm{t} / \mathrm{ha}$ for the same variety. Another study also reported that setting a spacing of $90 \times 20 \mathrm{~cm}$ resulted in a much higher trunk weight and cob weight per plant compared to the $75 \times 20 \mathrm{~cm}$ and $60 \times 20 \mathrm{~cm}$ spacings commonly applied by farmers. The application of a double row planting system with a spacing of $90-70 \times 20 \mathrm{~cm}$ was able to give the highest yield of maize, reached 9.15 t/ha compared to a single row or single row planting system at a spacing of $70 \times 30 \mathrm{~cm}$ which only obtained a yield of $7,18 \mathrm{t} / \mathrm{ha}$ (Alislami and Suryanto, 2020).

This study aimed to evaluate growth and yield of maize cultivation using a double row planting system inoculated with mycorrhizae and different rows of mungbean insertion in dry land of Eastern Lombok, Indonesia.

\section{MATERIALS AND METHODS OF RESEARCH}

This study was conducted in Labuhan Lombok Village, Pringgabaya District, East Lombok Regency, WNT Province, Indonesia at a geographical position of $-8,51408,116,6554,15,2 \mathrm{~m}, 1170$ (Figure 1) from August to December 2019. The experiment was arranged according to a Randomized Block Design by testing 2 treatment factors, namely (1) Mycorrhizal Inoculation (M) consisting of two levels (M0 = without mycorrhizal inoculation; M1 = with mycorrhizal inoculation), (2) the number of mungbean inserted (D) consisting of three levels (D0 = maize cultivation without mungbean inserted; D1 = maize cultivation with 1 row of mungbean inserted; D2 = maize cultivation with 2 rows of mungbean inserted) and each treatment was replicaated 3 times therefore there were 18 experimental plots. 


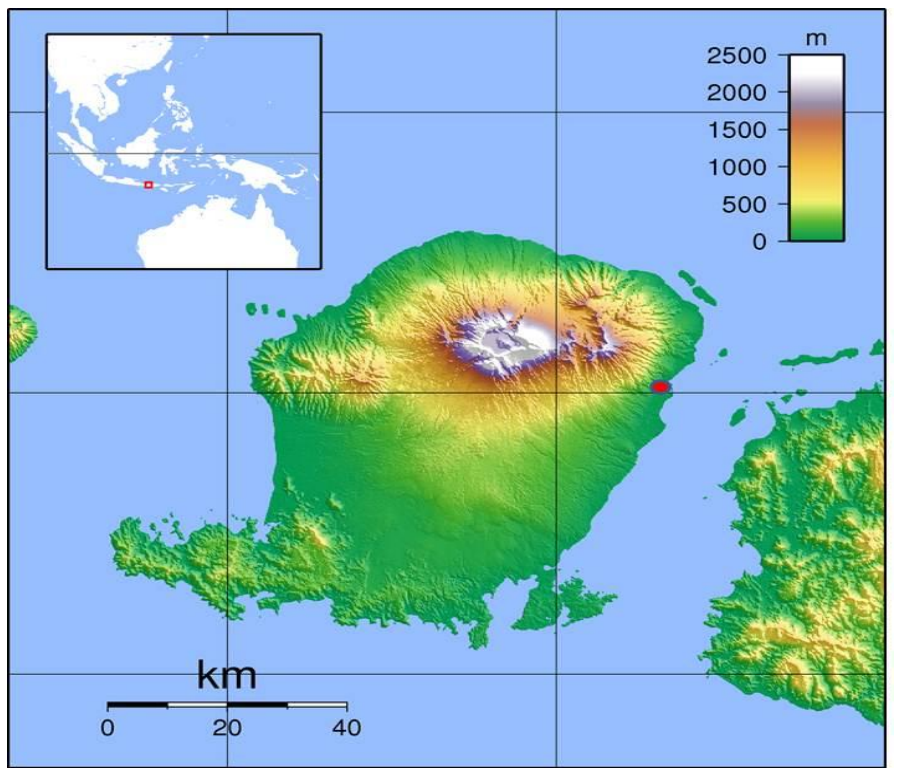

Figure 1 - Map of Lombok Island where the experimental site is in Labuhan Haji Village, East Lombok Regency, West Nusa Tenggara Province, Indonesia with red dot sign in the eastern part of the map

Tillage was applied to a minimum and 18 treatment plots were made with a size of $4 \mathrm{x}$ $2 \mathrm{~m}$. Drainage channels between treatment plots were made with a distance of $100 \mathrm{~cm}$ and within the plots between treatments were made as wide as $50 \mathrm{~cm}$. Maize planted in a single way, at a distance of $100 \mathrm{~cm}-50 \times 20 \mathrm{~cm}$ as many as $2-3$ seeds per planting hole. Before planting, maize seeds were mixed with an insecticide with metalaxyl active ingredients. Thinning was done when the maize plants were 7 days after planting, leaving 1 plant per hole. Mycorrhizae was given at the same time as planting at a dose of $8 / \mathrm{g}$ plant, by sowing mycorrhizae in the planting hole and then covering it with soil and planting maize seeds on it. The mycorrhizae used in this study were AMF Tecknofert produced by BPPT Serpong, Indonesia. Mungbean were planted individually, with a spacing of $33 \times 20 \mathrm{~cm}$.

\begin{tabular}{|llllll}
\hline$x$ & $x$ & $x$ & $x$ & $x$ & $x$ \\
$x$ & $x$ & $x$ & $x$ & $x$ & $x$ \\
$x$ & $x$ & $x$ & $x$ & $x$ & $x$ \\
$x$ & $x$ & $x$ & $x$ & $x$ & $x$ \\
$x$ & $x$ & $x$ & $x$ & $x$ & $x$ \\
$x$ & $x$ & $x$ & $x$ & $x$ & $x$ \\
$x$ & $x$ & $x$ & $x$ & $x$ & $x$ \\
$x$ & $x$ & x & $x$ & X & $x$ \\
\hline
\end{tabular}

\begin{tabular}{|cccccccc|}
\hline $\mathrm{x}$ & $\mathrm{x}$ & 0 & $\mathrm{x}$ & $\mathrm{x}$ & 0 & $\mathrm{x}$ & $\mathrm{x}$ \\
$\mathrm{x}$ & $\mathrm{x}$ & 0 & $\mathrm{x}$ & $\mathrm{x}$ & 0 & $\mathrm{x}$ & $\mathrm{x}$ \\
$\mathrm{x}$ & $\mathrm{x}$ & 0 & $\mathrm{x}$ & $\mathrm{x}$ & 0 & $\mathrm{x}$ & $\mathrm{x}$ \\
$\mathrm{x}$ & $\mathrm{x}$ & 0 & $\mathrm{x}$ & $\mathrm{x}$ & 0 & $\mathrm{x}$ & $\mathrm{x}$ \\
$\mathrm{x}$ & $\mathrm{x}$ & 0 & $\mathrm{x}$ & $\mathrm{x}$ & 0 & $\mathrm{x}$ & $\mathrm{x}$ \\
$\mathrm{x}$ & $\mathrm{x}$ & 0 & $\mathrm{x}$ & $\mathrm{x}$ & 0 & $\mathrm{x}$ & $\mathrm{x}$ \\
$\mathrm{x}$ & $\mathrm{x}$ & 0 & $\mathrm{x}$ & $\mathrm{x}$ & 0 & $\mathrm{x}$ & $\mathrm{x}$ \\
$\mathrm{x}$ & $\mathrm{x}$ & 0 & $\mathrm{x}$ & $\mathrm{x}$ & 0 & $\mathrm{x}$ & $\mathrm{x}$ \\
\hline & & & $\mathrm{B}$ & & & &
\end{tabular}

\begin{tabular}{|c|c|c|c|c|c|c|c|}
\hline$X$ & $x$ & 00 & $x$ & $X$ & 00 & $x$ & $x$ \\
\hline$x$ & $X$ & 00 & $x$ & $X$ & 00 & $X$ & $x$ \\
\hline$x$ & $x$ & 00 & $x$ & $x$ & 00 & $X$ & $x$ \\
\hline$x$ & $x$ & 00 & $X$ & $X$ & 00 & $X$ & $x$ \\
\hline$x$ & $X$ & 00 & $x$ & $X$ & 00 & $x$ & $x$ \\
\hline$x$ & $x$ & 00 & $X$ & $X$ & 00 & $X$ & $X$ \\
\hline$x$ & $x$ & 00 & $x$ & $X$ & 00 & $x$ & $x$ \\
\hline$x$ & $x$ & 00 & $x$ & $x$ & 00 & $X$ & $x$ \\
\hline
\end{tabular}

Figure 2 - Layout of treatment $(A=$ maize crop without inserting of mungbean), ( $B=$ maize crop (o) inserting 1 row of mungbean), ( $\mathrm{C}=$ maize crop (o) with inserting of 2 rows of mungbean)

The first fertilization on maize was given when the plant was 7 days after sowing (DAS) using NPK Phonska fertilizer at a dose of $250 \mathrm{~kg} / \mathrm{ha}$ which was applied in a single way at a distance of $3-5 \mathrm{~cm}$ by following the row of plants and then covered with soil. The second fertilization was given when the plants were 30 days after sowing using Urea fertilizer at a dose of $125 \mathrm{~kg} / \mathrm{ha}$. Fertilization of mungbean was only given once when the plant was 7 DAS using NPK Phonska fertilizer at a dose of $200 \mathrm{~kg} / \mathrm{ha}$ which was applied by putting in the hole at a distance of $3-5 \mathrm{~cm}$. Weeding was conducted three times, when the maize were 2, 4 and 7 weeks after sowing (WAS) by manually removing the nuisance plants. Maize irrigation was given 7 times and mungbean was given 5 times with watering intervals of 2 weeks which was applied with the flooding system. Pest and disease control uses the principles of integrated 
pest control (IPM). Maize harvest was carried out when the plants show the criteria for brown cobs, the dry husk population reaches $95 \%$ and the seeds were shiny. Mungbean harvest was conducted when the plant was 60 DAS when showing the criteria for dry pod skin and brown to black color.

The variables observed were: 1) growth components included plant height, number of leaves, leaf length and leaf width and 2) yield components included ear length, ear diameter, number of rows of seeds per ear, number of seeds per row, weight of 100 seeds, weight dry density and dry seed weight and plant nutrient uptake. Data were analyzed using analysis of variance (ANOVA) and honest significant difference test at a significance level of $5 \%$ using the CoStat for Windows ver. 6,303. Correlation analysis was also conducted to determine the degree of relationship between observed variables using the Minitab Rail program. 13.20.

\section{RESULTS AND DISCUSSION}

The results of the Analysis of Variance (ANOVA) showed that the application of mycorrhizae and the insertion of the number of rows of mungbean between maize plant had a significant effect on the growth and yield and the level of nutrient uptake of maize plant, while the interaction of the application of mycorrhizae with the insertion of a different number of rows of mungbean only had a significant effect on the variable length of cobs and maize nutrient uptake rate (Table 1).

Table 1 - Summary of the ANOVA results on all variables observed in maize

\begin{tabular}{|c|c|c|c|}
\hline Variables & Mycorrhizae & Inserting & Interaction \\
\hline Relative Growth Rate (RGR) Plant Height & $* \star *$ & * & NS \\
\hline Relative Growth Rate (RGR) Number of Leaves & *** & NS & NS \\
\hline Leaf Lenght & NS & NS & NS \\
\hline Leaf Width & * & NS & NS \\
\hline Number of Leaves above the Cob & NS & NS & NS \\
\hline Number of Dry Leaves & * & NS & NS \\
\hline Length of Cobs & *** & ** & * \\
\hline Diamteter of Cobs & *** & NS & NS \\
\hline Number of rows per cob & ** & * & NS \\
\hline Number of seeds per row & NS & * & NS \\
\hline Weight of 100 seeds & NS & NS & NS \\
\hline Plant dry weight & ** & NS & NS \\
\hline Seed dry weight & * & NS & NS \\
\hline Mycorrizhal inoculation & *** & NS & NS \\
\hline $\mathrm{N}$ nutrient uptake & *** & $\star * *$ & $\star \star \star *$ \\
\hline $\mathrm{P}$ nutrient uptake & * & $\star * *$ & $* * *$ \\
\hline K nutrient uptake & *** & *** & NS \\
\hline
\end{tabular}

Note: $n s=$ non-significant; ${ }^{*}{ }^{* * ;}{ }^{* * *}=$ significant at $p<0.05 ; p<0.01 ; p<0.001$ respectively.

The benefits of AMF in plants have been widely reported. The association of AMF with plants provides beneficial values, one of which can increase root capacity in the absorption of P, N, K, Zn, Cu, S, Ca and Mg nutrients (Cruz et al., 2004; Swift, 2004; Suh, 2005). Increased nutrient uptake is related to the ability of mycorrhizae which can increase the reach of roots to get water and nutrients in the soil with the help of external hyphae. These external hyphae are able to explore beyond the range of plant roots therefore the absorption of water and nutrients becomes better (Drew, 2002). In addition, root growth in mycorrhizal inoculated plants will help improve nutrient status (Astiko and Wangiyana, 2018).

Based on the effect of each treatment (main effect) on the parameters of growth and yield as well as nutrient uptake (Tables 2 and 3 ), all growth and yield components as well as the percentage of plant nutrient uptake in mycorrhizal inoculation were much higher than plants without mycorrhizal inoculation. This is presumably because mycorrhizal inoculation can increase the ability and efficiency of plants in absorbing N, P and K nutrients to support plant growth and yield. The structure of arbuscular mycorrhizal hyphae in plant roots and soil is able to expand the area for exchange of nutrients and water between plants and hosts, so 
it has considerable potential to increase nutrient uptake and translocation, especially $P$ to plants. Phosphorus is an important constituent of high-energy substrates (ATP, ADP, AMD) which plays a role in plant metabolism. Plant metabolism activities that are supported by sufficient energy can develop reproductive organs in a sustainable manner, as the end result is an increase in the weight of 100 seeds followed by an increase in dry seed weight.

Table 2 - Average Relative Growth Rate (RGR) plant height (cm), Relative Growth Rate (RGR) number of leaves (strands), leaf length $(\mathrm{cm})$, leaf width $(\mathrm{cm})$, number of leaves above the cob

(strands), number of dry leaves (strands), plant dry weight (g)

\begin{tabular}{|c|c|c|c|c|c|c|c|c|c|c|c|c|c|c|}
\hline \multirow{2}{*}{$\begin{array}{l}\text { Treatment } \\
\text { M1 }\end{array}$} & \multicolumn{2}{|l|}{$\begin{array}{l}\text { RGR } \\
\text { Plant } \\
\text { Height }\end{array}$} & \multicolumn{2}{|c|}{$\begin{array}{l}\text { RGR } \\
\text { Number of } \\
\text { Leaves }\end{array}$} & \multicolumn{2}{|c|}{$\begin{array}{l}\text { Leaf } \\
\text { Length }\end{array}$} & \multicolumn{2}{|c|}{$\begin{array}{l}\text { Leaf } \\
\text { Width }\end{array}$} & \multicolumn{2}{|c|}{$\begin{array}{l}\text { Number of } \\
\text { Leaves above } \\
\text { the cob }\end{array}$} & \multicolumn{2}{|c|}{$\begin{array}{l}\text { Number of } \\
\text { dry leaves }\end{array}$} & \multicolumn{2}{|c|}{$\begin{array}{l}\text { Plant dry } \\
\text { weight }\end{array}$} \\
\hline & 78.22 & a & 3.35 & $a$ & 80.36 & a & 8.15 & a & 5.77 & $\mathrm{a}$ & 1.47 & b & 185.42 & a \\
\hline MO & 70.82 & $b$ & 3.10 & $b$ & 79.56 & a & 7.59 & $b$ & 5.66 & a & 1.86 & a & 133.15 & b \\
\hline HSD & 3.34 & & 0.10 & & 4.29 & & 0.50 & & 0.32 & & 0.33 & & 30.98 & \\
\hline J0 & 70.66 & $b$ & 3.30 & a & 80.80 & a & 8.10 & a & 5.91 & a & 1.75 & a & 162.17 & a \\
\hline J1 & 76.03 & a & 3.20 & a & 79.07 & a & 7.62 & a & 5.75 & a & 1.62 & a & 146.71 & a \\
\hline J2 & 76.86 & a & 3.18 & a & 80.00 & a & 7.89 & a & 5.50 & a & 1.62 & a & 168.97 & a \\
\hline HSD & 5.04 & & 0.15 & & 6.46 & & 0.76 & & 0.48 & & 0.51 & & 46.68 & \\
\hline
\end{tabular}

The numbers in each column followed by the same letter, are not significantly different between the levels of each treatment factor, according to the honest significant different (HSD) at a 5\% significance level.

In addition to nutrient $\mathrm{P}$, the increase in $\mathrm{N}$ uptake in maize also helps increase the rate of carbohydrate transfer to seeds, because seed filling is affected by the ability to supply $\mathrm{N}$ to leaves and seeds, as reported by Wangiyana et al., (2018) that leaf weight per ha provides the largest contribution to cob weight per ha. This is supported by the statement of Sinclair and de Wit (2007) if the supply of $\mathrm{N}$ from $\mathrm{N}$ uptake is inadequate, then the plant will remobilize $\mathrm{N}$ from green leaves to seeds, which will cause an increase in the rate of leaf aging.

Nutrient $\mathrm{K}$ also has an important role in plant metabolic processes, ranging from photosynthesis, assimilate translocation to the formation of starch, protein and enzyme activator (Karama et al., 1992). Potassium is very mobile, mostly found in vegetative parts of plants, especially in young tissues (Odjak, 1992). Wihardjaka et al., (2002) reported that there was a positive correlation between total $\mathrm{K}$ uptake and grain yield of rice plants which showed a very significant closeness $(p<0.01)$ with the correlation coefficient between $K$ uptake and grain yield was $0.91^{* *}$. In addition, mycorrhizae also act as biological controllers, increase resistance to water stress and produce hormones and growth regulators that function to increase plant growth and yield (Hildebrandt et al., 2002). In addition, Moelyohadi (2019) reported that application of mycorrhizae at a dose of $10 \mathrm{~g} /$ plant gave the best effect, where the average yield/ha was able to reach 13.47 tons of dry cobs/ha.

Table 3 - Average diameter of the cob $(\mathrm{cm})$, Number of rows/cob, Number of seeds/row, Weight of 100 grains (g), Dry weight of seeds (g), Mycorrhizal inoculation (\%), N Nutrient uptake (\%), P Nutrient uptake (\%), K nutrient uptake (\%)

\begin{tabular}{|c|c|c|c|c|c|c|c|c|c|c|c|c|c|c|c|c|c|c|}
\hline \multirow{2}{*}{$\begin{array}{l}\text { Treatment } \\
\text { M1 }\end{array}$} & \multicolumn{2}{|c|}{$\begin{array}{l}\text { Cob } \\
\text { Diameter }\end{array}$} & \multicolumn{2}{|c|}{$\begin{array}{l}\text { Number of } \\
\text { rows/cob }\end{array}$} & \multicolumn{2}{|c|}{$\begin{array}{l}\text { Number of } \\
\text { seeds/cob }\end{array}$} & \multicolumn{2}{|c|}{$\begin{array}{l}\text { Weight of } \\
100 \text { grains }\end{array}$} & \multicolumn{2}{|c|}{$\begin{array}{l}\text { Dry weight } \\
\text { of seeds }\end{array}$} & \multicolumn{2}{|c|}{$\begin{array}{l}\text { Mycorrhizal } \\
\text { Inoculation }\end{array}$} & \multicolumn{2}{|c|}{$\begin{array}{l}\mathrm{N} \text { nutrient } \\
\text { uptake }\end{array}$} & \multicolumn{2}{|c|}{$\begin{array}{l}\mathrm{P} \text { nutrient } \\
\text { uptake }\end{array}$} & \multicolumn{2}{|c|}{$\begin{array}{l}\text { K nutrient } \\
\text { uptake }\end{array}$} \\
\hline & 34.49 & $a$ & 15.33 & $a$ & 30.25 & $a$ & 26.02 & $a$ & 117.10 & $a$ & 45.08 & $a$ & 1.57 & $a$ & 0.37 & $a$ & 2.48 & $a$ \\
\hline Mo & 28.09 & b & 14.00 & b & 27.44 & a & 24.63 & a & 98.01 & b & 17.97 & $b$ & 1.10 & b & 0.34 & b & 2.28 & b \\
\hline HSD & 2.29 & & 0.83 & & 3.08 & & 2.46 & & 13.74 & & 2.80 & & 0.01 & & 0.02 & & 0.03 & \\
\hline JO & 33.01 & $a$ & 15.33 & $a$ & 32.08 & $a$ & 26.78 & $a$ & 111.50 & $a$ & 29.36 & $a$ & 1.21 & C & 0.24 & c & 2.13 & b \\
\hline J1 & 29.42 & $b$ & 13.91 & $b$ & 26.62 & $b$ & 24.17 & a & 103.02 & a & 32.26 & a & 1.36 & b & 0.37 & b & 2.48 & a \\
\hline J2 & 31.44 & $a b$ & 14.75 & $a b$ & 27.83 & $a b$ & 25.01 & a & 108.15 & a & 32.96 & a & 1.45 & a & 0.47 & a & 2.52 & a \\
\hline HSD & 3.45 & & 1.25 & & 4.65 & & 3.71 & & 20.71 & & 4.23 & & 0.02 & & 0.03 & & 0.05 & \\
\hline
\end{tabular}

The numbers in each column followed by the same letter, are not significantly different between the levels of each treatment factor, according to the honest significant difference (HSD) test at a 5\% significance level.

The insertion of 2 rows of mungbean between maize plants through a double row spacing arrangement with the addition of mycorrhizal inoculations in addition to increasing plant dry weight and seed dry weight, can also help increase mycorrhizal infection and plant 
nutrient uptake which was much higher than the insertion of 1 row of mungbean, while the average of all observation variables at the insertion of 2 rows of mungbean was lower than that of maize without mungbean insertion, where there was a decrease in yield of $6 \%$ which was $7.20 \mathrm{t} / \mathrm{ha}$ compared to maize without mungbean insertion which reached $7.69 \mathrm{t} / \mathrm{ha}$, while the decrease in maize yields with the insertion of one row of mungbean was about $11 \%$, which was $6.86 \mathrm{t} / \mathrm{ha}$.

The higher productivity of maize plants with the insertion of two rows of mungbean compared to the insertion of one row of mungbean was thought to be due to the contribution of $\mathrm{N}$ from mungbean plants to maize plants. With the insertion of two rows of mungbean at the same spacing of maize, the rhizosphere position of the mungbean rows is closer to the rhizosphere of maize plants compared to the insertion of one row of mungbean, as reported by Wangiyana et al., (2018) that the insertion of 3 rows of peanuts significantly increased the weight of the cob per ha compared to the insertion of one row of peanuts.

In addition, the application of the double row planting system provides optimal conditions for plants, where the double row planting system is an engineering planting system by adjusting the spacing between plants and between rows where compaction of maize plants occurs in rows and widens the distance between rows so that the intensity of solar radiation. The reflection received by plants can increase the photosynthesis process and the photosynthate yield can be maximized and have a positive influence on plant growth and yield (Sesanti, et al., 2014; Nurbaiti et al., 2017).

Based on the correlation analysis between seed dry weight and other observation variables, the number of seeds/row and mycorrhizal inoculation showed a positive and significant correlation coefficient, this means that the number of seeds/row and mycorrhizal infection gave the largest contribution to the dry weight of seeds, with the determinant coefficient or $R^{2}=48.9 \%$ for the number of seeds/row and the determinant coefficient or $R^{2}=$ $37 \%$ for mycorrhizal inoculation.

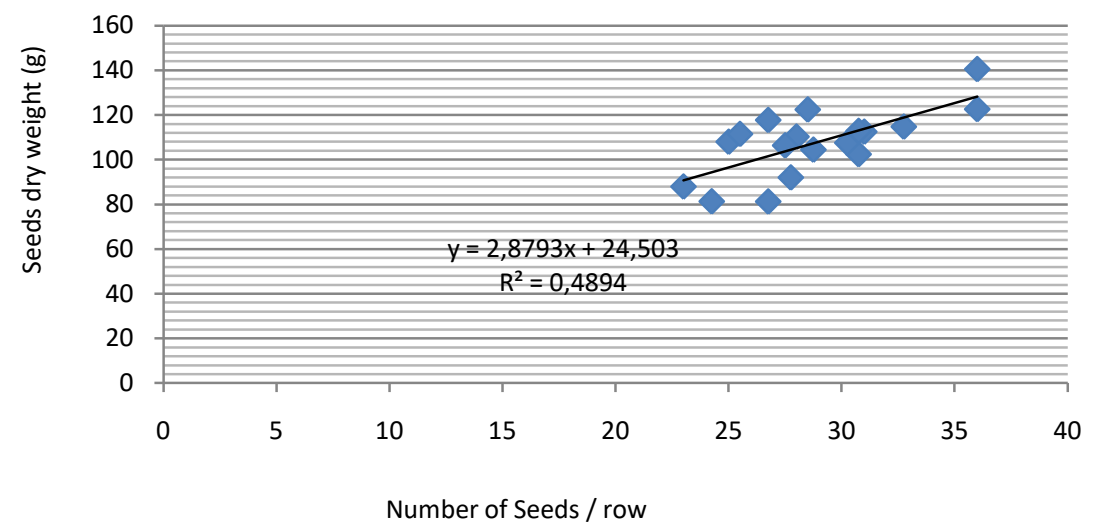

Figure 3 - Regression coefficient of number of seeds/rows and dry weight of seeds

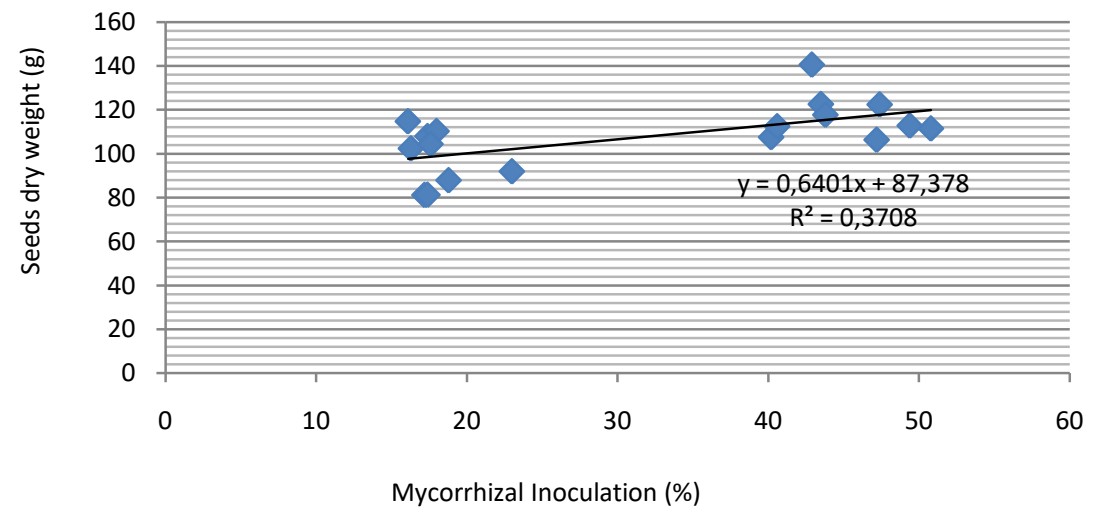

Figure 4 - Regression coefficient of mycorrhizal infection and seed dry weight 
In relation to this correlation, especially the percentage of mycorrhizal inoculation which has a positive effect on the efficiency of N, P and K nutrient uptake so as to support plant growth and yield. Increased $\mathrm{N}$ uptake in maize also helps increase the rate of carbohydrate transfer to seeds, because seed filling is affected by the ability to supply $\mathrm{N}$ to leaves and seeds. Nutrient $\mathrm{K}$ also has an important role in plant metabolic processes, ranging from photosynthesis, assimilate translocation to the formation of starch, protein and enzyme activator.

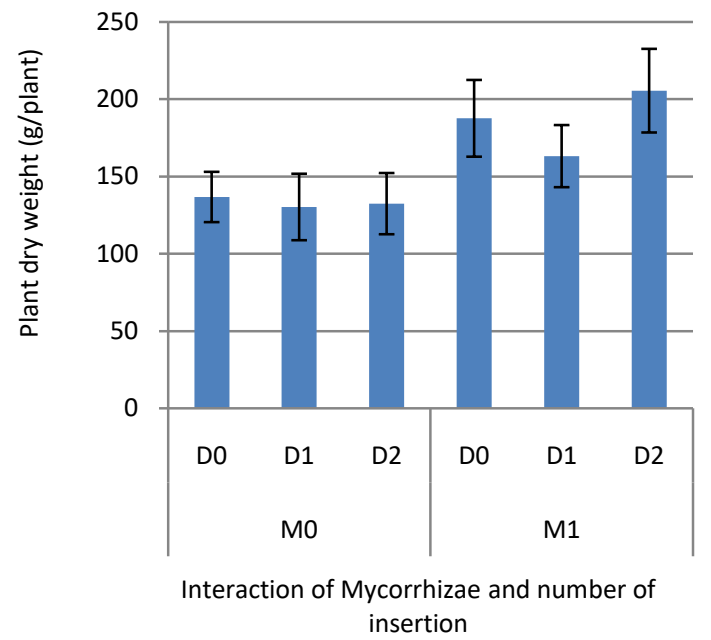

Figure 5 - Average (Mean SE) dry weight

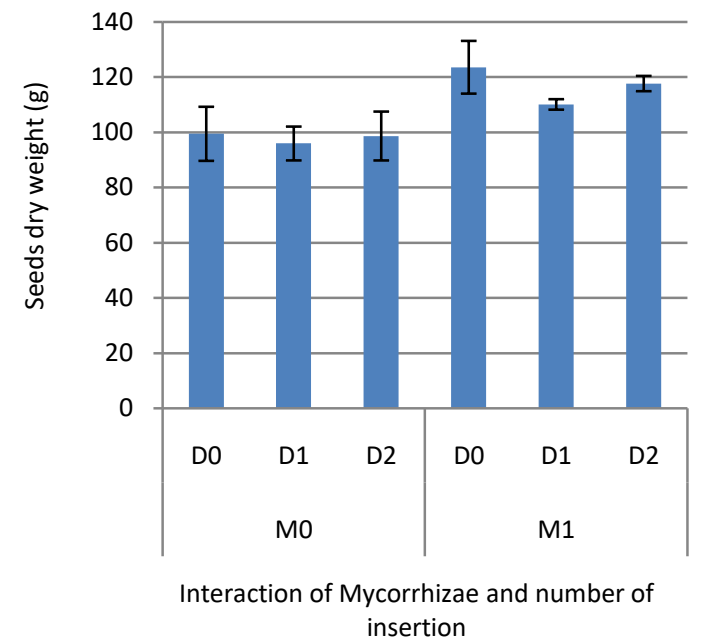

Figure 6 - Mean (Mean SE) dry weight of seeds

(g) of plants $(\mathrm{g})$ for treatment combinations

Based on the interaction effect of treatment on plant dry weight and seed dry weight, it can be seen that mycorrhizal inoculation showed a positive effect compared to no mycorrhizal inoculation. The number of insertions of two rows of mungbean also contributed positively to the dry weight of the plant compared to maize plants without mycorrhizal inoculation or without inserting mungbean and the insertion of one row of mungbean, but in the dry weight variable of seeds, monocroping maize plants or those without mungbean insertion showed higher yield compared to the insertion of two rows and the insertion of one row of mungbean. This is presumably because the maize plants without mungbean insertion do not compete in the absorption of nutrients, water or other growth factors so that the results obtained are much better than the maize plants with insertion.

Based on an evaluation of the land equivalence ratio based on the total yield of each component of intercropping in one hectare (Mao et al., 2012) it was shown that double row maize planting inoculated with mycorrhizae by inserting 1 row of mungbean resulted in far higher Land Equivalence Ratio (LER) than the insertion of 2 rows of mungbean, namely 2.62 and 2.25 (LER $>1)$, respectively. This means that the application of the intercropping system of maize and mungbean on dry land in dry climates with the addition of mycorrhizal inoculation is able to provide efficiency in land use. The LER was used to determine the measure of yield advantage, where a good treatment combination based on the results obtained was planting mycorrhizae inoculated maize with the insertion of 1 row of mungbean.

\section{CONCLUSION}

Maize planting in dry land with dry climate with double row planting system inoculated with mycorrhizae and insertion of two rows of mungbean was much better than inserting 1 row of mungbean because the difference in yield obtained was much smaller, namely $6 \%$ or $490 \mathrm{~kg}$ compared to monoculture yields, but from the results of the profit evaluation based on the calculation of the LER, the insertion of 1 row of mungbean was much higher, namely 2.62 compared to the insertion of two rows of mungbean which only obtained a result of 2.25. 


\section{CONFLICT OF INTERESTS}

Authors clearly declare that they have no competing interests.

\section{CONTRIBUTORSHIP} paper.

All authors contributed equally during the process of preparing and publishing this

\section{ACKNOWLEDGEMENTS}

The authors would like to thank all staffs at the IP2TP Sandubaya Research Station West Nusa Tenggara Assessment Institute for Agricultural Technology for all their assistance during the field experiment in 2019.

\section{REFERENCES}

1. Alislami, T. C. K., Suryanto, A. (2020). Pengaruh Sistem Tanam dan Mulsa terhadap Efisiensi Konversi Radiasi pada Tanaman Jagung (Zea mays Var. Identata) Varietas Pertiwi 3. Produksi Tanaman. 8(1): 158-165.

2. Astiko, W., Wangiyana, W. (2018). Respon Pola Tanam Jagung-Sorgum terhadap Beberapa Paket Pemupukan Berbasis Mikoriza Indegenus dan Bahan Organik di Lahan Kering Lombok Utara. Sains Teknologi \& Lingkungan. 4(2): 153-163.

3. Drew, E. A. (2002). External AM hyhae: Their Growth and Function in Media of Varying Pore Sizes. PhD thesis. Departement of Soil and Water,The University of Adelaide, Adelaide, Australia.

4. Erawati, B. T. R., Herawati, N., Widiastuti, E. (2013). Peran PTT Jagung dalam Peningkatan Produksi dan Finansial: Kasus di Desa Donggobolo Kecamatan Woha Kabupaten Bima NTB. Seminar Nasional Serealia. 252-263.

5. Farida, N., Wiresyamsi, A., Budianto, V. F. A., Dahlan, M., Dulur, N. W. D., Wangiyana, W. (2014). Pertumbuhan dan Hasil Tanaman Jagung Ketan pada Berbagai Jarak Tanam, Pola Barisan dan Tumpangsari dengan Tanaman Legum di Lahan Sawah Entisol. Agroteksos. 24(1): 1-8.

6. Hildebrandt, U., Janette, K. and Bothe, H. (2002). Towards Growth of Arbuskular Mychorrizal Fungi Independent of a Plant Host. Appl. Environ. Microbiol. 68: 1919-1924.

7. Jaya I. K. D., Sudirman, Rosmilawati. (2017). Exploring strip intercropping potentials of maize pulse crops to fight climate variability impacts in dryland areas. International Journal of Bioscience and Biotechnology. vol. 5, hal 1-11.

8. Karama, A. S., Adiningsih, J. S., Supartini, M., Sediarso, M., Kasno, A. Prihatini, T. (1992). Peranan pupuk kalium dalam peningkatan produktivitas lahan pertanian di Indonesia. p. 9-48. dalam Peranan Kalium dalam Pemupukan Berimbang untuk Mempercepat Swasembada Pangan. Prosiding Seminar Nasional Kalium. Jakarta, 4 Agustus 1992.

9. Mao, L., Zhang, L., Li, W., Werf, W., Sun, J., Spiertzand, H., Li, L. (2012). Yield Advantage and Water Saving in Maize/ Pea Intercrop. Field Crops Research 138.

10. Muliany, P. H. (2018). Outlook Komoditas Pertanian Tanaman Pangan Jagung. Pusat Data dan Sistem Informasi Pertanian. Kementerian Pertanian.

11. Moelyohadi, Y. (2019). Pemanfaatan Kompos Limbah Tanaman Padi dan Pemberian Mikoriza terhadap Pertumbuhan dan Produksi Tanaman Jagung (Zea mays L.) Pada Lahan Kering Masam. Klorofil. XIV(1): 53-62.

12. Nurbaiti, F., Haryono, G. Suprapto, A. (2017). Pengaruh Pemberian Mulsa dan Jarak Tanam pada Hasil Tanaman Kedelai (Glycine max (L.) Merrill) Varietas Grobogan. Ilmu Pertanian Tropika dan Subtropika. 2(2): 41-47.

13. Odjak, M. (1992). Effect of potassium fertilizer in increasing quality and quantity of crop yield. p. 94-104. dalam Peranan kalium dalam pemupukan berimbang untuk 
mempercepat swasembada pangan. Prosiding Seminar Nasional Kalium. Jakarta, 4 Agustus 1992.

14. Sesanti, R. N., Wentasari, R., Ismad, W., Yanti, W. F. (2014). Perbandingan Pertumbuhan dan Produksi Jagung Manis (Zea mays saccharata L.) pada Sistem Tanam Satu Baris dan Dua Baris. Agrovigor. 7(2): 76-84.

15. Sinclair, T. R. and de Wit C. T. (1975). Photosynthate and Nitrogen Requirements for Seed Production by Various Crops. Science, 189: 565-567.

16. Smith, S. E, Read, D. J. (2008). Mycorrhizal Symbiosis. Third edition. Academic Press, New York, USA.

17. Wangiyana, W., Gunartha, I. G. K., Farida, N. (2018). Respon Beberapa Varietas Jagung pada Jarak Tanam Berbeda terhadap Penyisipan Beberapa Baris Kacang Tanah. Crop Agro. II(2): 104-112.

18. Wangiyana, W., Aryana, I. G. P. M., Gunartha, I. G. E., Dulur, N. W. D. (2018). Tumpangsari dengan Kedelai dan Inokulasi dengan Mikoriza Arbuskular untuk Meningkatkan Produksi Malai pada Berbagai Galur Harapan Padi Gogo dan Ampibi Beras Merah pada Sistem Aerobik. Prosiding Seminar Nasional Lingkungan Lahan Basah. 3(2): 388-393.

19. Wihardjaka, K. A., Idris, K., Rachim, A. dan S. Partohardjono, S. (2002). Pengelolaan Jerami dan Pupuk Kalium pada Tanaman Padi di Lahan Sawah Tadah Hujan. J. Penelitian Pertanian Tanaman Pangan. 21(1): 26-32. 